\title{
Use of Opuntia ficus-indica (L.) Mill extracts from Brazilian Caatinga as an alternative of natural moisturizer in cosmetic formulations
}

\author{
Gabriel Azevedo de Brito Damasceno, Rebeca Manuelle Alexandre da Costa Silva, Júlia Morais \\ Fernandes, Elissa Arantes Ostrosky, Silvana Maria Zucolotto Langassner, Márcio Ferrari"
}

College of Pharmacy, Department of Pharmacy. University of Rio Grande do Norte, Natal, RN, Brazil

\begin{abstract}
The aim of this work was the obtainment of Opuntia ficus-indica (L.) Mill extract for the development of cosmetic formulations and in vivo evaluation of its moisturizing effects. The formulations were tested for preliminary and accelerated stability. Organoleptic characteristics, $\mathrm{pH}$ values and rheological behavior were assessed. The evaluation of moisturizing efficacy of the emulsions formulated with $3.0 \%$ of Polyacrylamide (and) C13-14 Isoparaffin (and) Laureth-7 containing 1.0 and 3.0\% of O. ficus-indica hydroglycolic extract (EHG001) was performed using the capacitance method (Corneometer $\left.{ }^{\circledR}\right)$ and the transepidermal water loss - TEWL evaluation (Tewameter $\left.{ }^{\circledR}\right)$. The emulsions formulated were stable, exhibiting pseudoplastic and thixotropic behavior. The results of evaluation of moisturizing efficacy showed increased skin hydration after five hours by mainly increasing the skin barrier effect. The formulations containing 1.0 and 3.0\% of EHG001 enhanced the skin barrier effect by reducing TEWL up to four hours after application. The results observed suggest that $O$. ficus-indica hydroglycolic extract may act through a humectant and occlusion mechanism.
\end{abstract}

Uniterms Opuntia ficus indica/emulsion stability. Opuntia ficus indica/cosmetic efficacy. Skin/cosmetics/ use/efficacy

\section{INTRODUCTION}

The barrier function and maintenance of the water content of the skin largely depends on intercellular lipids and the natural moisturizing factor (NMF) present in the stratum corneum. A healthy stratum corneum under normal conditions has from 15 to $20 \%$ water content. When the amount of water declines to below $10 \%$, the skin takes on dry characteristics (Barco, Giménez-Arnau, 2008; Baroni et al., 2012).

The active compounds used in cosmetics for skin hydration can be divided into two major groups: hydrophilic and lipophilic agents, which act by occlusion, as humectants, via active hydration by rearranging the stratum corneum and by inducing the formation of aquaporins (Caussin et al., 2009; Ribeiro, 2010; Bonté, 2011).

*Correspondence: M. Ferrari. Universidade Federal do Rio Grande do Norte. Av. General Gustavo de Farias - Petrópolis, 59012-370 - Natal - RN, Brasil. Tel/Fax.: +55 843342 9838. E-mail: ferrarimarcio@uol.com.br
Cosmetic formulations must present physical and chemical stability against factors such as temperature variations and vibrations from the transport of the product, have good spreadability and skin sensorial effect, as well as to promote the incorporation and release of the active compounds appropriately, besides ensuring the safety of the components that come into contact with the skin (Breuer, 1985).

In stability studies, several procedures are used to accelerate possible instability phenomena present in formulations, such as submitting them to temperature changes and temperature cycling, the application of centrifugal forces, and vibration (Tadros, 2004; Guaratini et al., 2006).

Among the parameters evaluated in stability studies, the determination of the rheological behavior must be used not only to evaluate physical stability of formulations, but also as a parameter indicating the system quality and relate to the purpose of the product developed (Tadros, 2004; Guaratini et al., 2006).

Cosmetic products also have to be investigated 
for efficacy and safety and bioengineering methods are used to assess the different situations. The applications of noninvasive biometrical methods are growing substantially and rapidly, including the determination of the effectiveness of natural ingredients in improving skin hydration (Piérard, 2002; Dal'Belo et al., 2006).

In this context, the measurement of transepidermal water loss (TEWL) is an indicator of the skin's barrier function. It is a method of assessing the skin barrier integrity. However, capacitance measurement is also indicative of an increase or decrease in water within the stratum corneum. This electrical property of the skin provides information that allows hydration levels to be calculated (Fluhr et al., 1999; Dykes, 2002; Heinrich et al., 2003; Darlenski et al., 2009; Gonçalves, Maia Campos, 2009a; Byrne, 2010; Sotoodian, Maibach, 2012).

Opuntia fícus-indica (L.) Mill (O. ficus-indica) is a Cactacea present in the Caatinga ecosystem, which represents an important source of food for animals and has economic importance (Ginestra et al., 2009).

Traditionally, species of $O$. ficus-indica are commonly used as a food source and for the treatment of arteriosclerosis, diabetes, hyperglycemia and gastritis (Ramadan, Mörsel, 2003; Stintzing, Carle, 2005). Thus, several studies have been conducted showing diuretic action (Galati et al., 2002a), antiulcer activity, increased production of gastric mucus and gastric protective activity (Galati et al., 2001; Galati et al., 2002b), wound healing (Park, Chun, 2001), antioxidant properties (Zhong et al., 2010), a protective effect in cartilage alteration (Panico et al., 2007) and hypoglycemic action (Butterweck et al., 2011).

Fresh cladodes of $O$. ficus-indica contain 88 to $95 \%$ water, 3 to $7 \%$ carbohydrate, 1 to $2 \%$ ash, 1 to $2 \%$ fiber, 0.5 to $1 \%$ protein and $0.2 \%$ lipids (Stintzing, Carle, $2005)$. The specie is also a source of calcium oxalate crystals that have an important role in water retention and osmotic pressure regulation. This action is also exerted by pectins and mucilages. The carbohydrate fraction is mainly composed of glucose and galacturonic acid, minor amounts of arabinose, galactose, mannose, xylose and rhamnose, and also traces of fucose and flavonoids such as rutin, quercetin and isoquercetin, isoharmetin and kaempferol (Ginestra et al., 2009). The presence of these metabolites in the chemical composition is of great interest to the cosmetics industry and thus led to this research.

The aim of this work was the obtainment of Opuntia ficus-indica (L.) Mill extract for the development of cosmetic formulations and in vivo evaluation of its moisturizing effects, after a single application while using noninvasive bioengineering techniques.

\section{MATERIAL AND METHODS}

\section{Preparation of $O$. ficus-indica extract}

The cladodes of $O$. ficus-indica were supplied by the Agricultural Research Corporation of Rio Grande do Norte, Brazil (5'17'27,71' S, 36 $\left.6^{\circ} 16^{\prime} 27,63^{\prime \prime} \mathrm{W}\right)$. A voucher specimen was deposited at the Herbarium of the Federal University of Rio Grande do Norte under number UFRN16600 .

The hydroglycolic extract was obtained from fresh cladodes. The cladodes were washed with distilled water, cut into small pieces and left to macerate for 12 hours. Subsequently, the resultant mixture was percolated under a flow of $2 \mathrm{~mL} / \mathrm{min}$ to obtain the extract. The extract was named EHG001.

\section{Formulations studied}

Ten formulations (Table I) were prepared with different types and concentrations of the structuring and emulsifier polymer used. The ingredients were named according to the International Nomenclature of Cosmetic Ingredients (INCI) convention. The preparation techniques were dependent on the polymers used.

Formulations containing Sodium Polyacrylate (and) Hydrogenated Polydecence (and) Trideceth-6, characterized as emulsions, were prepared by the method of cold emulsification under mechanical stirring at $500 \mathrm{rpm}$ (IKA, mod. RW 20 digital, Germany) for 35 minutes until full dispersion and homogeneity of the polymer system was achieved. The emulsions formulated with Polyacrylamide (and) C13-14 Isoparaffin (and) Laureth-7 were prepared similarly, under mechanical stirring at $350 \mathrm{rpm}$ for 20 minutes of homogenization.

The formulation prepared with Sodium Polyacrylate in gel form was prepared in one step. After hydration of the polymer, it was submitted to mechanical agitation (Ika, mod. RW 20 digital, Germany) at $500 \mathrm{rpm}$ for 35 minutes until complete dispersion of the polymer and formation of the gel.

The obtained formulations were subjected, 24 hours after manipulation, to a series of organoleptic and physical (phase separation and creaming) analyses and rheological behavior. The incorporation of $O$. ficus-indica hydroglycolic extract was further studied. The extract was directly added to the final step and mechanical agitation was applied under the same conditions used for five minutes. 


\section{Stability studies}

\section{Physical analysis}

The obtained formulations were analyzed for a series of organoleptic (color and odor) and physical (phase separation and creaming) parameters to identify potential unstable processes (Lima et al., 2008). Those stable formulations after physical analysis were stored in PVC pots and subjected to preliminary stability tests.

\section{Preliminary stability tests}

- Centrifugation test: After $24 \mathrm{~h}$, the samples were submitted to cycles of $3000 \mathrm{rpm}$ (Fanen, mod. 206 $\mathrm{BL}$, Brazil) for thirty minutes at room temperature (Lima et al., 2008).

- $\quad$ Thermal stress: Formulations were subjected to tests in a heated bath (Logen Scientific, mod. LSBMLS 2006-2, Brazil) set at the temperature range of 40 to $80^{\circ} \mathrm{C}$, with increasing temperature at intervals of 5 ${ }^{\circ} \mathrm{C}$, which was maintained for thirty minutes at each temperature. The organoleptic characteristics, determination of the $\mathrm{pH}$ and electric conductivity were obtained to evaluate the formulations before and at the end at $80^{\circ} \mathrm{C}$, after the natural cooling of the samples at room temperature $\left(25 \pm 2{ }^{\circ} \mathrm{C}\right)$ (Braconi et al., 1995).

- $\quad$ Freeze-defrost cycles: Samples stored at $4 \pm 2$ ${ }^{\circ} \mathrm{C} / 24$ hours (Mabe, mod. REMB460NFM2A2BR, Brazil) and $45 \pm 2{ }^{\circ} \mathrm{C} / 24$ hours (Fanen, mod. 515, Brazil), thus completing a cycle. The organoleptic characteristics, determination of the $\mathrm{pH}$ and electric conductivity were obtained to evaluate the formulations before and at the end of the sixth cycle (12th day) (Lima et al., 2008).

- Determination of the $\mathrm{pH}$ : In a test tube, $1.0 \mathrm{~g}$ of formulation and $9.0 \mathrm{~g}$ of distilled water were added, homogenized and the $\mathrm{pH}$ value was determined by inserting the electrode directly into the sample
(Hanna Instruments, mod. HI 21, Brazil) (Davis, 1977).

- Determination of electrical conductivity: The electrical conductivity of the formulation was evaluated at a temperature of $25 \pm 2{ }^{\circ} \mathrm{C}$ by inserting the electrode directly into the samples (Logen Scientific, mod. CD-300-K1, Brazil) (Pianovski et al., 2008).

\section{Accelerated Stability Tests}

The samples considered stable by preliminary tests were subjected to varying conditions of temperature and time: $25 \pm 2{ }^{\circ} \mathrm{C}, 4 \pm 2{ }^{\circ} \mathrm{C}$ (Mabe, mod. REMB460NFM2ABR, Brazil) and $45 \pm 2{ }^{\circ} \mathrm{C}$ and $75 \pm 5 \%$ RH (Nova Etica, mod. 520-CLDTS 150, Brazil). The parameters were evaluated at different time intervals $(24$ $\mathrm{h}$ after preparation of the formulations and on the 30th, 60 th and 90th days). The parameters analyzed in both the stability tests included macroscopic characteristics, $\mathrm{pH}$ values and rheological behavior (Ferrari, Rocha-Filho, 2011).

Determination of viscosity: Determination of the viscosity was performed on a Rheometer (Brookfieldmodel RV- EUA) cone and plate, which were coupled to Rheocalc software version V3.01 using the spindle CP 52 and $0.5 \mathrm{~g}$ of the sample at $25 \pm 2{ }^{\circ} \mathrm{C}$. Measurements were made using rotational speeds that progressively increased (1-10 rpm with variation at an interval of 2 at 2 $\mathrm{rpm}$ ) to obtain the ascending curve, and this procedure was repeated in reverse, with speeds that were progressively lower (10-1 rpm) to obtain the descending curve (Lima et al., 2008).

\section{Evaluation of in vivo efficacy}

This study was approved by the Research Ethics Committee of the University of Cuiabá (\#2012-041). A total of 12 volunteers between the ages of 20 and 65 years with no history of previous skin disease were included in this study after having given their written informed

TABLE I - Composition of formulations $(\% \mathrm{w} / \mathrm{w})$ for incorporation of $O$. ficus-indica extracts

\begin{tabular}{|c|c|c|c|c|c|c|c|c|c|c|}
\hline Ingredient & F1 & F2 & F3 & F4 & F5 & F6 & F7 & F8 & F9 & F10 \\
\hline $\begin{array}{l}\text { Sodium Polyacrylate (and) Hydrogenated } \\
\text { Polydecence (and) Trideceth-6 }\end{array}$ & 0.5 & 1.0 & 2.0 & 3.0 & - & - & - & - & - & - \\
\hline Sodium Polyacrylate & - & - & - & - & 0.5 & 1.0 & 1.5 & - & - & - \\
\hline $\begin{array}{l}\text { Polyacrylamide (and) C13-14 Isoparaffin } \\
\text { (and) Laureth-7 }\end{array}$ & - & - & - & - & - & - & - & 1.0 & 2.0 & 3.0 \\
\hline Disodium EDTA & 0.1 & 0.1 & 0.1 & 0.1 & 0.1 & 0.1 & 0.1 & 0.1 & 0.1 & 0.1 \\
\hline Phenoxyethanol, Caprylylglicol & 1.0 & 1.0 & 1.0 & 1.0 & 1.0 & 1.0 & 1.0 & 1.0 & 1.0 & 1.0 \\
\hline Distilled Water & 98.4 & 97.9 & 96.9 & 95.9 & 98.4 & 97.9 & 97.4 & 97.9 & 96.9 & 95.9 \\
\hline
\end{tabular}


consent. This study was designed as a one-sided blind, placebo-controlled study. The volunteers were instructed not to use any cosmetic products for two weeks before and on the day of the experiment, except cleaning products like soap.

This methodology was adapted from Faria, Damasceno and Ferrari (2014) and Maia Campos et al. (2012). Prior to all measurements, volunteers were left in the room for at least $30 \mathrm{~min}$ in order to allow full skin adaptation to the room's temperature $\left(20 \pm 2{ }^{\circ} \mathrm{C}\right)$ and humidity $(60 \pm 5 \%)$.

Six sites on volunteers' forearm skin were chosen (C1 to $\mathrm{C} 6$ ): one (C1) serving as the control where only measurements were taken, and the others ( $\mathrm{C} 2$ to $\mathrm{C} 6)$, to which different formulations, one without extract (vehicle), the formulation containing $1.0 \%$ of hydroglycolic extract of $O$. ficus-indica, the formulation containing $1.0 \%$ extractor solvent, the formulation containing $3.0 \%$ extract, and formulation containing 3.0\% extractor solvent, were applied, respectively. All formulations were applied to the surface of the skin at a dose of $2 \mathrm{mg} / \mathrm{cm}^{2}$ with a light massage of approximately $10 \mathrm{~s}$.

Stratum corneum moisture content was determined by noninvasive biometrical measurements using a skin capacitance meter (Courage \& Khazaka, Electronic $\mathrm{GmbH}$, Khöln, Germany) whereas transepidermal water loss was determined by an evaporimeter (Courage \& Khazaka, Electronic GmbH, Khöln, Germany). TEWL values were registered for 2 min following a $30 \mathrm{~s}$ period of equilibration of the probe on the skin. The baseline measurements (control area-region which received no formulation) of skin hydration were taken after at least 30 min of acclimatization under standard climatic conditions. Skin capacitance and TEWL were determined before, and at 1, 2, 3, 4 and $5 \mathrm{~h}$ after a single application of the formulations to fields $\mathrm{C} 2-\mathrm{C} 6$ and to the control field without formulation (C1). For skin capacitance measurement, nine readings were taken in each field. For TEWL evaluation, one reading in each field was taken.

Statistical analyses were performed using the software Graph Pad Prism 5. Univariate analysis of variance and the post hoc test were carried out by using Tukey's multiple comparison test and Dunnet's test ( $p<0.05$ was considered to be statistically significant) (Ribeiro et al., 2015).

\section{RESULTS AND DISCUSSION}

\section{Formulations studied}

All the formulations showed no changes in macroscopic parameters or phase separation, while no creaming was observed in the emulsions after the centrifugation test. Additionally, a linear relationship was not observed between shear rate and shear stress values, with a flow index below 1 indicating non-Newtonian, pseudoplastic behavior, characteristics desirable in cosmetic formulations (Guaratini et al., 2006; Tadros, 2011; Vianna-Filho et al., 2013).

Minimal apparent viscosity and consistency index values were dependent on the concentration of the structuring and emulsifier polymer used. Although the values were not in accordance with the technical literature provided by the manufacturer (Rapithix, 2003; Sepigel $305,2013)$, these results were similar to those obtained by Anchisi et al. (2001) for formulations containing polyacrylamide (and) C13-14 isoparaffin (and) Laureth-7.

Anchisi et al. (2001) evaluated the influence of four plant extracts in formulations prepared with concentrations ranging from 1.5 to $7.0 \%$ Polyacrylamide (and) C13-14 Isoparaffin (and) Laureth-7 and observed that the addition of the extracts led to a $20 \%$ reduction in the apparent viscosity of the formulations compared to vehicles. Thus, the formulations that showed the highest values in minimal apparent viscosity and consistency index (F4, F7 and F10) were chosen as the most suitable for incorporation of the $O$. ficus-indica hydroglycolic extract obtained and continuation of the studies.

\section{Stability studies}

\section{Preliminary stability tests}

Results of preliminary stability tests of F4, F7 and F10 formulations with the addition of $1 \%$ EHG001 are shown in Table II. Creaming, sedimentation or phase separation can result from gravity. Therefore, centrifugation can be applied to accelerate these instability processes (Tadros, 2004). No changes in the macroscopic parameters, phase separation or creaming of the emulsions after the centrifugation test were observed, representing a positive indication of stability.

The F7 formulation showed statistically significant differences $(p<0.05)$ after thermal stress when compared with initial $\mathrm{pH}$ values. Changes in $\mathrm{pH}$ values can indicate chemical reactions and degradation of the formulation ingredients and may also be related to the incorporation of $\mathrm{pH}$-dependent components (Ferrari, 2002).

One of the most used procedures for assessing phase inversion is to measure the electrical conductivity as a function of changes in temperature (Tadros, 2004). Decreases in conductivity values can be related to phase inversion (Tadros, 2004) while increases in these values 
TABLE II - Results of preliminary stability tests of F4, F7 and F10 formulations added with 1\% of EHG001

\begin{tabular}{lcccccc}
\hline \multirow{2}{*}{ Formulation } & \multicolumn{3}{c}{ pH values } & \multicolumn{3}{c}{ Electrical conductivity (mS) } \\
\cline { 2 - 7 } & $\begin{array}{c}\text { Initial } \\
\text { (After 24 h) }\end{array}$ & $\begin{array}{c}\text { After frost/ } \\
\text { defrost cycles }\end{array}$ & $\begin{array}{c}\text { After thermal } \\
\text { stress }\end{array}$ & $\begin{array}{c}\text { Initial } \\
\text { (After 24 h) }\end{array}$ & $\begin{array}{c}\text { After Frost/ } \\
\text { defrost cycles }\end{array}$ & $\begin{array}{c}\text { After thermal } \\
\text { stress }\end{array}$ \\
\hline F4 & $6.70 \pm 0.04$ & $6.70 \pm 0.04$ & $6.77 \pm 0.08$ & $4.25 \pm 0.20$ & $4.31 \pm 0.08$ & $4.40 \pm 0.10^{*}$ \\
F7 & $6.61 \pm 0.03$ & $6.61 \pm 0.02$ & $6.70 \pm 0.03 *$ & $3.08 \pm 0.07$ & $3.05 \pm 0.05$ & $3.12 \pm 0.04$ \\
F10 & $5.71 \pm 0.10$ & $5.66 \pm 0.06$ & $5.72 \pm 0.09$ & $2.17 \pm 0.04$ & $2.10 \pm 0.07^{*}$ & $2.17 \pm 0.03$ \\
\hline
\end{tabular}

$* p$-value $>0.05$. Data were expressed as means and standard deviations.

can be caused by three main factors: (i) diffusion of an electrolyte; (ii) phenomenon of coalescence; or even (iii) destruction of the oil interface (Wen, Papadopoulos, 2001; Pays et al., 2002). F10 formulation showed a statistically significant $(\mathrm{p}<0.05)$ decrease in electrical conductivity values after frost/defrost cycles while F4 showed a statistically significant $(p<0.05)$ increase in values after thermal stress, all of which could be related to system instability.

Preliminary stability involves screening tests and studies used in the initial phase of product development (Anvisa, 2005). These studies use extreme and different conditions to accelerate the potential reactions between components and demonstrate the most common instability processes of formulations (phase separation, flocculation and creaming) (Tcholakova et al., 2006). The conditions of these studies are not intended to estimate product shelf-life, but to provide formulation screening (Lima et al., 2008).

In this context, although the formulations showed significant variations in the evaluated parameters, when analyzed together, F4, F7 and F10 formulations were considered stable under conditions of the preliminary stability tests and were therefore evaluated by the accelerated stability tests.

\section{Accelerated Stability Tests}

The parameters evaluated in the accelerated stability study included macroscopic characteristics, $\mathrm{pH}$ value and minimal apparent viscosity. Additionally, index flow, consistency index and hysteresis area were calculated to determine the rheological profile of the formulations. Results of accelerated stability tests are shown in Table III. The macroscopic characteristics of all formulations remained stable after the 90 days of study for the three storage conditions.

The F4 formulation showed significant changes in the $\mathrm{pH}$ values of the samples stored at $25^{\circ} \mathrm{C}$ while $\mathrm{F} 7$ and F10 showed statistically significant differences for the samples stored at 25 and $45^{\circ} \mathrm{C}$.
Mahmood and Akhtar (2013) studied the stability of multiple emulsions containing green tea extract, and observed significant changes in $\mathrm{pH}$ values for those formulations stored at $40{ }^{\circ} \mathrm{C}$. These variations were attributed to the degradation of green tea components. Therefore, the changes observed in the present study may be related to degradation of both the active components of the extract used and the structural components of the formulations.

The analysis of viscosity values showed significant variations for the $\mathrm{F} 7$ formulation stored at 4 and $25{ }^{\circ} \mathrm{C}$ after 90 days of the study. According to Tadros (2004), a decrease or increase in viscosity during storage indicates instability of the system. For F4 and F10 formulations, no statistically significant changes in the viscosity values were evident over the duration of the experiment (90 days), indicating good stability of the samples.

According to the Cosmetic Products Stability Guide (Anvisa, 2005), the products have an acceptable variation of $\pm 5 \%$. The changes observed in $\mathrm{pH}$ values for all three formulations were below the values recommended by the Brazilian Health Surveillance Agency (ANVISA). However, the F7 formulation showed variations close to $10 \%$ above the recommended values and was considered unstable. These results, associated with macroscopic characteristics, characterized the F4 and F10 formulations as stable.

Addition of emulsifiers represents a commonly used method to stabilize the structure of emulsions for cosmetic products, besides the rheological characteristics, sensorial aspects must also be evaluated (Moravkova, Filip, 2013). Additionally, other studies (Anchisi et al., 2001; Gonçalves, Maia Campos, 2009b) have reported the development of stable emulsions containing one of the polymers used in our formulations (Polyacrylamide (and) C13-14 Isoparaffin (and) Laureth-7) at different concentrations lower than those used in our formulations. Therefore, it is possible to relate the better structuring of the F4 and F10 formulations to the consequent impact on the rheological parameters, which had a network- 
structuring agent and emulsifier. By contrast, F7 had a structuring agent which proved insufficient to maintain a stable system under accelerated stability conditions.

The stable emulsions F4 and F10 showed nonNewtonian behavior (Figure 1), given that they did not exhibit a non-linear relationship between shear stress and shear rate (Tadros, 2004). Flow index and consistency index were calculated using the Herschel-Bulkley model. The flow index values (Table III) were below 1.0 , indicating pseudoplastic flow behavior (Guaratini et al., 2006). Pseudoplastic behavior is suitable for topical application products where, after shearing, the initial resistance to the emulsion flow decreases, reflected in ease of application, a desirable rheological property for cosmetic products (Tadros, 2004; Guaratini et al., 2006).

According to Tadros (2004), thixotropic products become more fluid when exposed to an external pressure, and spread more easily in the region where they are applied, whereby the initial viscosity recovers when the application ceases, as a function of time. The ascending and descending curves show hysteresis, often referred to as a thixotropic loop. The F4 emulsion (Figure 1a) shows the descending curve below the ascending curve and the hysteresis area (Table III) indicates thixotropy in the system.

However, the F10 emulsion (Figure $1 \mathrm{~b}$ ) has some curves exhibiting thixotropic behavior and others exhibiting antithixotropic behavior. In antithixotrophy, the descending curves of rheograms are situated above the ascending curve, which may indicate that shearing can promote temporary aggregation (Dutschk et al., 2012). According to Dutschk et al. (2012), this variation can be caused by two main factors: lack of homogeneity in the emulsion preparation or the effect of pre-shear during the
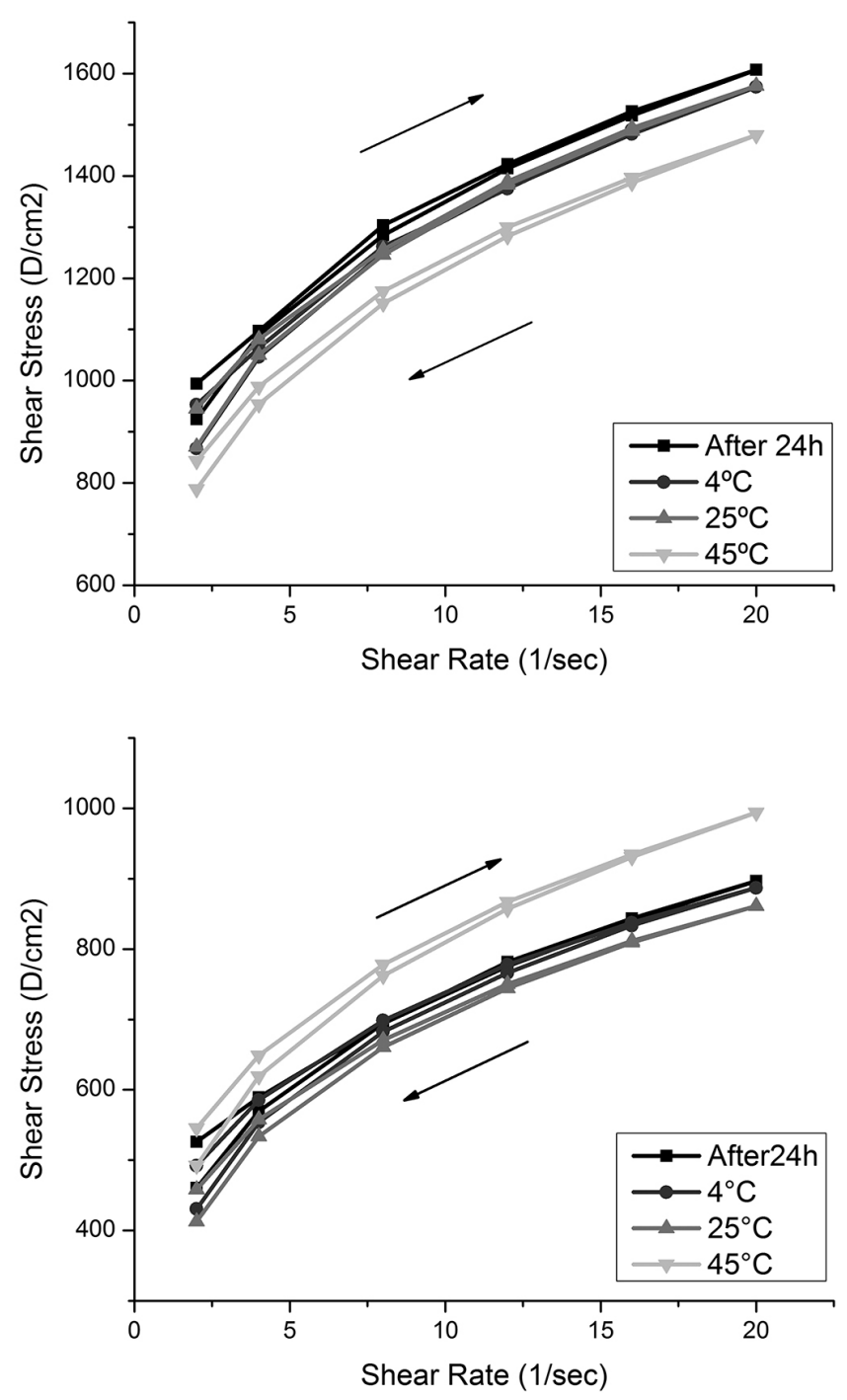

FIGURE 1 - (a) F4 formulation rheogram after 24 hours and 90 days, stored at 4,25 and $45^{\circ} \mathrm{C}$. (b) F10 formulation rheogram after 24 hours and 90 days, stored at 4,25 and $45^{\circ} \mathrm{C}$.

TABLE III - Results of accelerated stability tests after $24 \mathrm{~h}$ and 90 days

\begin{tabular}{|c|c|c|c|c|c|c|c|c|c|c|c|c|}
\hline & \multicolumn{4}{|c|}{ F4 } & \multicolumn{4}{|c|}{ F7 } & \multicolumn{4}{|c|}{ F10 } \\
\hline & \multirow{2}{*}{ After $24 \mathrm{~h}$} & \multicolumn{3}{|c|}{ After 90 days } & \multirow{2}{*}{ After 24 h } & \multicolumn{3}{|c|}{ After 90 days } & \multirow{2}{*}{ After 24 h } & \multicolumn{3}{|c|}{ After 90 days } \\
\hline & & $4^{\circ} \mathrm{C}$ & $25^{\circ} \mathrm{C}$ & $45^{\circ} \mathrm{C}$ & & $4^{\circ} \mathrm{C}$ & $25^{\circ} \mathrm{C}$ & $45^{\circ} \mathrm{C}$ & & $4{ }^{\circ} \mathrm{C}$ & $25^{\circ} \mathrm{C}$ & $45^{\circ} \mathrm{C}$ \\
\hline $\begin{array}{l}\text { Macroscopic } \\
\text { characteristics }\end{array}$ & $\mathrm{N}$ & $\mathrm{N}$ & $\mathrm{N}$ & $\mathrm{N}$ & $\mathrm{N}$ & $\mathrm{N}$ & $\mathrm{N}$ & $\mathrm{N}$ & $\mathrm{N}$ & $\mathrm{N}$ & $\mathrm{N}$ & $\mathrm{N}$ \\
\hline $\mathrm{pH}$ value & $\begin{array}{c}6.71 \pm \\
0.04\end{array}$ & $\begin{array}{c}6.69 \pm \\
0.07\end{array}$ & $\begin{array}{l}6.85 \pm \\
0.04^{*}\end{array}$ & $\begin{array}{c}6.75 \pm \\
0.06\end{array}$ & $\begin{array}{c}6,66 \pm \\
0.41\end{array}$ & $\begin{array}{c}6.67 \pm \\
0.06\end{array}$ & $\begin{array}{c}6.85 \pm \\
0.02 *\end{array}$ & $\begin{array}{l}6.78 \pm \\
0.03^{*}\end{array}$ & $\begin{array}{c}5.58 \pm \\
0.04\end{array}$ & $\begin{array}{c}5.65 \pm \\
0.06\end{array}$ & $\begin{array}{c}5.78 \pm \\
0.02 *\end{array}$ & $\begin{array}{c}5.74 \pm \\
0.03^{*}\end{array}$ \\
\hline $\begin{array}{l}\text { Minimal apparent } \\
\text { viscosity }\end{array}$ & $\begin{array}{c}8287.07 \pm \\
184.81\end{array}$ & $\begin{array}{c}8279.33 \pm \\
244.42\end{array}$ & $\begin{array}{c}8208.80 \pm \\
305.82\end{array}$ & $\begin{array}{c}7828.46 \pm \\
219.07\end{array}$ & $\begin{array}{c}6173.69 \pm \\
377.42\end{array}$ & $\begin{array}{c}6737.04 \pm \\
217.04 *\end{array}$ & $\begin{array}{c}6729.32 \pm \\
227.01 *\end{array}$ & $\begin{array}{l}6188.02 \pm \\
267.30\end{array}$ & $\begin{array}{c}4779.09 \pm \\
272.09\end{array}$ & $\begin{array}{c}4786.81 \pm \\
290.68\end{array}$ & $\begin{array}{c}4726.18 \pm \\
269.72\end{array}$ & $\begin{array}{c}4832.01 \pm \\
168.16\end{array}$ \\
\hline Index flow & $\begin{array}{c}0.33 \pm \\
0.03\end{array}$ & $\begin{array}{c}0.28 \pm \\
0.03\end{array}$ & $\begin{array}{c}0.28 \pm \\
0.04\end{array}$ & $\begin{array}{c}0.28 \pm \\
0.02\end{array}$ & $\begin{array}{c}0.43 \pm \\
0.05\end{array}$ & $\begin{array}{c}0.38 \pm \\
0.03\end{array}$ & $\begin{array}{c}0.36 \pm \\
0.02\end{array}$ & $\begin{array}{c}0.33 \pm \\
0.02\end{array}$ & $\begin{array}{c}0.30 \pm \\
0.05\end{array}$ & $\begin{array}{c}0.23 \pm \\
0.03\end{array}$ & $\begin{array}{c}0.26 \pm \\
0.03\end{array}$ & $\begin{array}{c}0.24 \pm \\
0.02\end{array}$ \\
\hline Consistency index & $\begin{array}{c}47855.67 \pm \\
9046.27\end{array}$ & $\begin{array}{c}65406.00 \pm \\
13640.63\end{array}$ & $\begin{array}{c}66610.78 \pm \\
17119.72\end{array}$ & $\begin{array}{c}62132.00 \pm \\
7462.48\end{array}$ & $\begin{array}{c}22496.56 \pm \\
6425.83\end{array}$ & $\begin{array}{c}27707.11 \pm \\
10130.92\end{array}$ & $\begin{array}{c}34460.89 \pm \\
3096.73\end{array}$ & $\begin{array}{c}38946.22 \pm \\
4558.24\end{array}$ & $\begin{array}{c}36613.56 \pm \\
10951.44\end{array}$ & $\begin{array}{c}56053.56 \pm \\
11327.88\end{array}$ & $\begin{array}{c}46039.67 \pm \\
8135.97\end{array}$ & $\begin{array}{c}51972.44 \pm \\
7641.94\end{array}$ \\
\hline Hysteresis area & $\begin{array}{c}252.24 \pm \\
188.87\end{array}$ & $\begin{array}{c}275.56 \pm \\
132.02\end{array}$ & $\begin{array}{c}313.65 \pm \\
162.99\end{array}$ & $\begin{array}{c}379.33 \pm \\
60.20\end{array}$ & $\begin{array}{c}-307.54 \pm \\
110.09 *\end{array}$ & $\begin{array}{c}-166.94 \pm \\
68.42 *\end{array}$ & $\begin{array}{c}-92.22 \pm \\
72.75^{*}\end{array}$ & $\begin{array}{c}-75.33 \pm \\
102.80^{*}\end{array}$ & $\begin{array}{c}-40.57 \pm \\
118.37 *\end{array}$ & $\begin{array}{l}76.07 \pm \\
117.20 *\end{array}$ & $\begin{array}{l}9.92 \pm \\
76.71^{*}\end{array}$ & $\begin{array}{l}91.06 \pm \\
96.21^{*}\end{array}$ \\
\hline
\end{tabular}

$\mathrm{N}=$ Normal; $*$ p-value $>0.05$. Data were expressed as means and standard deviations. 
transfer of the emulsion to the rheometer.

\section{Evaluation of in vivo efficacy}

The evaluation of in vivo moisturizing efficacy was performed with the F10 formulation since, among stable formulations, this had the best sensorial evaluation (results not shown). In order to recommend a range of use and determine the influence of concentration of the extract, another formulation with the same composition of F10 containing 3.0\% EHG001 extract was also prepared and tested. The latter was not subjected to a stability test. However, no phase separation was observed in the centrifuge test and organoleptic characteristics and homogeneity were retained throughout the duration of the experiment with volunteers.

All volunteers had mean Corneometer values of below 40 a.u. and were therefore categorized as having dry skin (Leite-Silva et al., 2013; Courage-Khazaka, 2014). Table IV shows changes in skin hydration evaluated by the capacitance method on the Corneometer ${ }^{\circledR}$. A decrease in the values obtained for both the untreated control area (C1) as well as for the other areas that received treatment (C2 to C6) was noted.

Three hours after topical application, the $1.0 \%$ and $3.0 \%$ EHG001 formulations ( $\mathrm{C} 3$ and $\mathrm{C} 5$ ) showed higher values when compared with the vehicle $(\mathrm{C} 2)$ (statistically significant changes for $\mathrm{C} 5$ vs $\mathrm{C} 2$ ) and with applications of their corresponding formulations containing only the extractor solvent (C4 and C6). Only C5 showed higher values than the untreated control area, yet this difference was not statistically significant. Leite-Silva et al. (2013) found a similar profile when evaluating skin hydration and transepidermal water loss of coated zinc oxide nanoparticles. Although the values were higher than the untreated area, the test formulations were not statistically significant. According to the authors, in accordance with this study, the skin hydration profile showed a tendency to be higher after application of the formulations studied.

The analysis of the data obtained five hours after application of the formulations showed a similar profile to that observed after three hours. At this time, C5 values were higher than $\mathrm{C} 1$ and statistically significant differences were found when $\mathrm{C} 5$ was compared to $\mathrm{C} 2$ and $\mathrm{C} 6$. Thus, it can be concluded that the increase in skin hydration may be attributed to the $O$. ficus-indica extract and not to the vehicle or the solvent (propylene glycol: water 80:20 w/w) used in the extraction process.

The TEWL and skin barrier function evaluation showed that most of the volunteers had TEWL values below $10 \mathrm{~g} / \mathrm{h} / \mathrm{m}^{2}$ which characterized very healthy skin condition, according to the equipment manufacturer's technical literature (Courage-Khazaka, 2014).

Table V shows the result for the TEWL evaluation. It can be observed that, while the untreated control area (C1) showed a constant increase in TEWL as a function of time, the other treated areas had reduced or only slight increases in these values. Given the observed profile, use of ANOVA and Dunnett's test revealed statistically significant changes in TEWL after 1, 2, 3, 4 and 5 hours when compared to baseline values. Additionally, using ANOVA and Tukey's test, significant variations amongst $\mathrm{C} 1, \mathrm{C} 3$ and $\mathrm{C} 5$ values, 3 and $5 \mathrm{~h}$ after the application of the formulations were also observed.

Thus, $1 \mathrm{~h}$ after application of the formulations, EHG001 formulations (C3 and C5) were associated with greater reductions in TEWL compared to other areas, demonstrating the improvement in skin barrier function evidenced by reduced TEWL and improvement in skin hydration. This profile was maintained until $4 \mathrm{~h}$ after application of the formulations, where beyond this point the percentage variation of $\mathrm{C} 3$ and $\mathrm{C} 5$ was no longer

TABLE IV - Skin hydration values measured before and 1, 2, 3, 4 and 5 hours after topical application of formulations

\begin{tabular}{lcccccc}
\hline & C1 & C2 & C3 & C4 & C5 & C6 \\
\hline Basal & $39.09 \pm 4.88$ & $38.99 \pm 5.82$ & $39.10 \pm 5.38$ & $38.26 \pm 5.62$ & $38.63 \pm 5.55$ & $37.93 \pm 6.50$ \\
T1 & $36.86 \pm 5.75$ & $34.39 \pm 6.10$ & $35.76 \pm 7.19$ & $34.70 \pm 6.60$ & $36.54 \pm 6.12$ & $35.40 \pm 7.22$ \\
T2 & $37.23 \pm 5.86$ & $33.81 \pm 6.32$ & $35.60 \pm 6.22$ & $33.55 \pm 5.60$ & $35.71 \pm 5.33$ & $33.89 \pm 6.59$ \\
T3 & $36.26 \pm 5.98$ & $34.25 \pm 6.87^{*}$ & $35.75 \pm 6.57$ & $34.45 \pm 5.43$ & $37.42 \pm 5.79^{*}$ & $35.31 \pm 6.94$ \\
T4 & $37.24 \pm 6.09$ & $34.98 \pm 7.44$ & $37.04 \pm 7.48$ & $34.84 \pm 7.19$ & $38.06 \pm 6.23$ & $35.55 \pm 7.11$ \\
T5 & $39.07 \pm 6.39$ & $37.53 \pm 7.38^{*}$ & $38.96 \pm 6.70$ & $36.87 \pm 5.34$ & $40.25 \pm 6.41^{*}$ & $36.98 \pm 6.70^{*}$ \\
\hline
\end{tabular}

$*$ p-value $<0.05$ for ANOVA and Tukey. $\mathrm{C} 1=$ Untreated area control; $\mathrm{C} 2=$ Vehicle; $\mathrm{C} 3=$ Vehicle $+1.0 \% \mathrm{EHG001;} \mathrm{C} 4=$ Vehicle $+1.0 \%$ solvents; $\mathrm{C} 5=$ Vehicle $+3.0 \%$ EHG001; $\mathrm{C} 6=$ Vehicle $+3.0 \%$ solvents; Basal $=$ measurement performed before topical application. T1, T2, T3, T4 e T5 = measurement performed after 1, 2, 3, 4 e $5 \mathrm{~h}$ respective topical application. Data were expressed as means and standard deviations. 
TABLE V - TEWL values $\left(\mathrm{g} / \mathrm{mm}^{2}\right.$.h) measured before and 1, 2, 3, 4 and 5 hours after topical application of formulations

\begin{tabular}{lcccccc}
\hline & C1 & C2 & C3 & C4 & C5 & C6 \\
\hline Basal & $5.39 \pm 4.20$ & $6.90 \pm 3.88$ & $8.22 \pm 5.08$ & $7.27 \pm 1.98$ & $9.10 \pm 3.50$ & $8.71 \pm 1.86$ \\
T1 & $5.57 \pm 1.70$ & $5.89 \pm 1.87 \mathrm{a}$ & $7.39 \pm 1.66^{\mathrm{a}}$ & $6.84 \pm 1.73^{\mathrm{a}}$ & $7.84 \pm 2.57^{\mathrm{a}}$ & $8.34 \pm 2.08^{\mathrm{a}}$ \\
T2 & $6.01 \pm 1.30^{\mathrm{a}}$ & $6.48 \pm 1.53^{\mathrm{a}}$ & $7.50 \pm 1.71^{\mathrm{a}}$ & $7.26 \pm 1.90$ & $8.77 \pm 2.08^{\mathrm{a}}$ & $8.20 \pm 2.02^{\mathrm{a}}$ \\
T3 & $6.32 \pm 1.48^{\mathrm{ab}}$ & $6.65 \pm 1.21^{\mathrm{a}}$ & $7.60 \pm 1.57^{\mathrm{ab}}$ & $7.87 \pm 1.44^{\mathrm{a}}$ & $8.48 \pm 1.56^{\mathrm{ab}}$ & $8.91 \pm 1.44$ \\
T4 & $6.22 \pm 1.42^{\mathrm{a}}$ & $6.76 \pm 1.26$ & $7.01 \pm 1.58^{\mathrm{a}}$ & $7.72 \pm 1.30^{\mathrm{a}}$ & $8.70 \pm 1.33^{\mathrm{a}}$ & $8.34 \pm 2.11^{\mathrm{a}}$ \\
T5 & $6.49 \pm 0.99^{\mathrm{ab}}$ & $7.18 \pm 1.00^{\mathrm{a}}$ & $7.98 \pm 1.91^{\mathrm{ab}}$ & $7.77 \pm 2.45^{\mathrm{a}}$ & $9.23 \pm 3.26^{\mathrm{b}}$ & $10.10 \pm 4.90^{\mathrm{a}}$ \\
\hline
\end{tabular}

${ }^{\mathrm{a}} \mathrm{p}$-value $<0.05$ for ANOVA and Dunntts; ${ }^{\mathrm{b}} \mathrm{p}$-value $<0.05$ for ANOVA + Tukey. $\mathrm{C} 1=$ Untreated area control; $\mathrm{C} 2=$ Vehicle; $\mathrm{C} 3=$ Vehicle $+1.0 \%$ EHG001; C4 $=$ Vehicle $+1.0 \%$ solvents; $\mathrm{C} 5=$ Vehicle $+3.0 \%$ EHG001; $6=$ Vehicle $+3.0 \%$ solvents; Basal $=$ measurement performed before topical application. T1, T2, T3, T4 e T5 = measurement performed after 1, 2, 3, 4 e $5 \mathrm{~h}$ respective topical application. Data were expressed as means and standard deviations.

statistically significant compared to baseline values ( $p$-value $<0.05$ for ANOVA and Dunnett's), although they continued to exert the effect described.

Figure 2 shows the percentage changes in TEWL values. While the untreated control area $(\mathrm{C} 1)$ had increased TEWL as a function of time (17.24\% and $20.36 \%$ after 3 and $5 \mathrm{~h}$, respectively), the areas where the 1.0 and $3.0 \%$ EHG001 formulations were applied decreased in this parameter as a function of time. The protective effect of skin, and consequent reduction in TEWL, observed in $\mathrm{C} 3$ and C5 was higher than in C2 (vehicle), as well as their corresponding formulations containing the extractor solvent whose protective effect had already decreased after three hours. Thus, it can be concluded that at one hour after application of formulations containing $O$. ficus-indica hydroglycolic extract, the protective barrier function of the skin is promoted, an effect that persists until $4 \mathrm{~h}$ after application of the formulations. At this time, there was a decline in the barrier function promoted by 1.0 and $3.0 \%$ EHG001 formulations.

The appeal of using cosmetics with moisturizing effects related to plant extracts is large. Thus, Kapoor and Saraf (2010) assessed the hydration effect of twenty commercially available herbal moisturizers, containing different herbs, on human skin, through the capacitance method, some of which increased the level of skin hydration by $80 \%$. However, in the cited study the authors attributed the hydration increase to the incorporated herbs without mentioning or analyzing the extracting solvent alone. The design of the present study allowed us to identify whether the moisturizing effect was truly due to the extract studied.

Leite e Silva et al. (2009) evaluated stratum corneum hydration after treatment with different moisturizers containing urea, herbal extracts, NMF components and carbohydrate compound as active substances. The authors

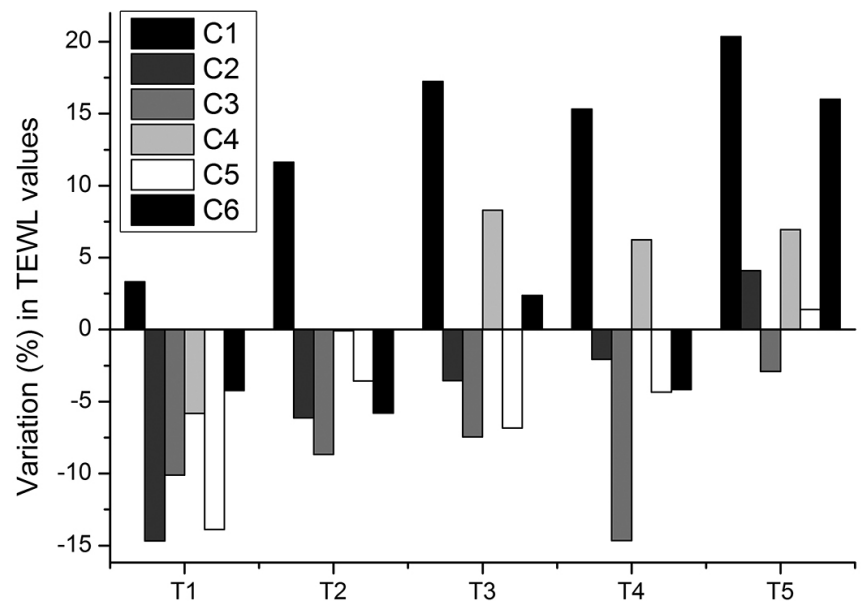

FIGURE 2 - Percentage changes in TEWL values calculated before and 1,2,3,4 and 5 hours after topical application of formulations. $\mathrm{C} 1=$ Untreated area control; $\mathrm{C} 2=$ Vehicle; $\mathrm{C} 3=$ Vehicle $+1,0 \%$ EHG001; C4 $=$ Vehicle $+1.0 \%$ solvents; $\mathrm{C} 5=$ Vehicle $+3.0 \%$ EHG001; 6 $6=$ Vehicle $+3.0 \%$ solvents; Basal $=$ measurement performed before topical application. T1, T2, T3, $\mathrm{T} 4 \mathrm{e}$ T5 $=$ measurement performed after 1, 2, 3, 4 e $5 \mathrm{~h}$ respective topical application.

observed that the gel added with urea and the carbohydrate derivate produced the most intense moisturizing effect.

In this context, another study was performed regarding the moisture-preserving activity of polysaccharides extracted from papaya using an in vitro system and the moisture absorption and retention compared to hyaluronic acid and glycerol was observed. This showed the potential to be used as a natural moisturizer (Zhang et al., 2012). Wang et al. (2013) studied moisture-absorption and retention of seven polysaccharides from algae and the results showed that the all of them had a better effect than hyaluronic acid. In this 
way, different studies (Lins, Pereira, Hünenberger, 2004; Futrakul et al., 2010; Ribeiro, 2010; Ohtake, Wang, 2011; Wharton, 2011; Du et al., 2013) using plant extracts have attributed moisturizing efficacy to polysaccharides even when used in low concentrations.

In addition to the polysaccharides, polyphenols, among them flavonoids, are of great importance in cosmetology due to their antioxidant action and benefits to the skin (Gianeti et al., 2013). Gianeti, Mercury and Maia Campos (2013) evaluated the effects of cosmetic formulations containing green tea hydroglycolic extract rich in polyphenols. Skin hydration and TEWL were studied, concluding that the formulations containing green tea extract promoted an increase in skin hydration and moisturizing effect.

Ribeiro et al. (2015) studied nanoemulsions containing 1.0 and $3.0 \%$ of $O$. ficus-indica hydroglicolic extract obtained by the same method used on our research. The authors observed a statistically significant increase of skin hydration after the application and this effect lasted for $5 \mathrm{~h}$. However, they did not observe a statistically significant alteration of TEWL and barrier function when compared with basal measurements. This could be associated with the smaller droplet size compared to our conventional emulsion, which increases permeability through the skin layers (Morganti, 2010) and proves that the vehicle could influence the moisturizing process mechanism (Polaskova, Pavlackova, Egner, 2015; Ribeiro et al., 2015).

Considering that the literature reports the presence of carbohydrates and flavonoids in the chemical composition of $O$. ficus indica cladodes, we suggest the moisturizing effect of the stratum corneum and the barrier effect and reduction in TEWL values promoted by $O$. ficus indica extract may be related to the presence of these metabolites, suggesting a humectant and mainly occlusion mechanism.

\section{CONCLUSIONS}

Under the experimental and standardized conditions in this study, it was concluded that the F4 formulation (3.0\% Sodium Polyacrylate (and) Hydrogenated Polydecence (and) Trideceth-6) and the F10 formulation (3.0\% Polyacrylamide (and) C13-14 Isoparaffin (and) Laureth-7) with addition of $1.0 \%$ EHG001, were stable.

The evaluation of in vivo moisturizing efficacy was performed with the F10 formulation with the addition of 1.0 and $3.0 \%$ O. ficus-indica extract in order to evaluate the influence of the extract concentration.

Results showed that the formulation with $3.0 \%$
EHG001 increased skin hydration after five hours compared to the vehicle $(7.25 \%)$ and to the corresponding formulation containing the extractor solvent $(8.85 \%)$. The formulations containing 1.0 and $3.0 \%$ EHG001 both increased the skin barrier effect by reducing TEWL (6.84 and $14.66 \%$, respectively) up to four hours after application when compared to the untreated control area, the vehicle and the solvent formulations. The emulsion with $3.0 \%$ EHG001 shows both an increase of skin moisturizing and a reduction of the TEWL and in this way, demonstrated the best moisturizing effect. Thus, we can conclude that the increase in skin hydration and barrier function may be attributed to the O. ficus-indica extract and not to the vehicle or the solvent (propylene glycol: water $80: 20 \mathrm{w} / \mathrm{w}$ ) used in the extraction process, suggesting a humectant and occlusion mechanism.

\section{ACKNOWLEDGMENTS}

The authors are grateful to all volunteers for their cooperation. We also thank Ashland Inc. and Chemyunion Química for the gift of sample materials, Agricultural Research Corporation from Rio Grande do Norte, Brazil for the gift of plant samples Federal University of Rio Grande do Norte for grants (UFRN/REUNI).

\section{REFERENCES}

AGÊNCIA NACIONAL DE VIGILÂNCIA SANITÁRIA. ANVISA. Guia de estabilidade de produtos cosméticos. Brasília: Anvisa, 2005. 45p.

ANCHISI, C.; MACCIONI, A.M.; SINICO, C.; VALENTI, D. Stability studies of new cosmetic formulations with vegetable extracts as functional agents. Farmaco, v.56, n.5-7, p.427-431, 2001.

BARCO, D.; GIMÉNEZ-ARNAU, A. Xerosis: una disfunción de la barrera epidérmica. Actas Dermosifiliogr., v.99, n.9, p.671-682, 2008.

BARONI, A.; BUOMMINO, E.; DE GREGORIO, V.; RUOCCO, E.; RUOCCO, V.; WOLF, R. Structure and function of the epidermis related to barrier properties. Clin. Dermatol., v.30, n.3, p.257-262, 2012.

BONTÉ, F. Skin moisturization mechanisms: New data. Ann. Pharm. Fr., v.69, n.3, p.135-141, 2011. 
BRACONI, F.L.; OLIVEIRA, I.S.; BARONI, M.N.F.; ROCHA FILHO, P.A. Aplicação cosmética do óleo de canola, In: Congresso Latino Americano e Ibérico de Químicos Cosméticos. Congresso Latino Americano e Ibérico de Químicos Cosméticos, 12. Anais. São Paulo: Associação Brasileira de Cosmetologia, p.6-19, 1995.

BREUER, M.M. Encyclopedia of emulsion technology. New York: Marcel Dekker, 1985.

BUTTERWECK, V.; SEMLIN, L.; FEISTEL, B.; PISCHEL, I.; BAUER, K.; VERSPOHL, E.J. Comparative evaluation of two different Opuntia ficus-indica extracts for blood sugar lowering effects in rats. Phytother. Res., v.25, n.3, p.370$375,2011$.

BYRNE, A.J. Bioengineering and subjective approaches to the clinical evaluation of dry skin. Int. J. Cosmet. Sci., v.32, n.6, p.410-421, 2010.

CAUSSIN, J.; ROZEMA, E.; GOORIS, G.S.; WIECHERS, J.W.; PAVEL, S.; BOUWSTRA, J.A. Hydrophilic and lipophilic moisturizers have similar penetration profiles but different effects on SC water distribution in vivo. Exp. Dermatol., v.18, n.11, p.954-961, 2009.

COURAGE-KHAZAKA. Derma Unit SSC 3. Cologne, Germany, 2014. Avaiable at: $<$ http://www.courage-khazaka. de/index.php/en/products/scientific/150-3combineddevice>. Accessed on: 01 Sep. 2014.

DAL'BELO, S.E.; GASPAR, L.R.; MAIA CAMPOS, P.M. Moisturizing effect of cosmetic formulations containing Aloe vera extract in different concentrations assessed by skin bioengineering techniques. Skin Res. Technol., v.12, n.4, p.241-246, 2006.

DARLENSKI, R.; SASSNING, S.; TSANKOV, N.; FLUHR, J.W. Non-invasive in vivo methods for investigation of the skin barrier physical properties. Eur. J. Pharm. Biopharm., v.72, n.2, p.295-303, 2009.

DAVIS, H.M. Analysis of creams and lotions. In: SENSEL, A.J. (ed.). Newburger's manual of cosmetic analysis. Washington: Association Official Analytical Chemists, 1977. cap.4, p.32.

DU, B.; BIAN, Z.; XU, B. Skin health promotion effects of natural beta-glucan derived from cereals and microorganisms: a review. Phytother. Res., v.22, n.2, p. 159-166, 2013.
DUTSCHK, V.; CHEN, J.; PETZOLD, G.; VOGEL, R.; CLAUSSE, D.; RAVERA, F.; LIGGIERI, L. The role of emulsifier in stabilization of emulsions containing colloidal alumina particles. Colloid Surf. A, v.413, p.239-247, 2012.

DYKES, P.J. What are meters measuring? Int. J. Cosmet. Sci., v.24, n.4, p.241-245, 2002.

FARIA, W.C.S.; DAMASCENO, G.A.B.; FERRARI, M. Moisturizing effect of cosmetic formulation containing pequioil (Caryocar brasiliense) of Brazilian cerrado biome. Braz. J. Pharm. Sci., v.50, n.1, p.131-136, 2014.

FERRARI, M. Desenvolvimento e avaliação da eficácia fotoprotetora de emulsões múltiplas contendo metoxicinamato de etilexila e óleo de andiroba (Carapa guyanensis). 2002. 142p. (Ph.D. in Pharmaceutical Sciences). Faculty of Pharmaceutical Sciences of Ribeirão Preto, University of São Paulo, Ribeirão Preto, SP, 2002.

FERRARI, M.; ROCHA-FILHO, P.A. D. Multiple emulsions containing amazon oil: açaí oil (Euterpe oleracea). Rev. Bras. Farmacogn., v.21, n.4, p.737-743, 2011.

FLUHR, J.W.; GLOOR, M.; LAZZERINI, S.; KLEESZ, P.; GRIESHABER, R.; BERARDESCA, E. Comparative study of five instruments measuring stratum corneum hydration (Corneometer CM 820 and CM 825, Skicon 200, Nova DPM 9003, DermaLab). Part I. In vitro. Skin Res. Technol., v.5, n.3, p.161-170, 1999.

FUTRAKUL, B.; KANLAYAVATTANAKUL, M.; KRISDAPHONG, P. Biophysic evaluation of polysaccharide gel from durian's fruit hulls for skin moisturizer. Int. J. Cosmet. Sci., v.32, n.3, p.211-215, 2010.

GALATI, E.M.; MONFORTE, M.T.; TRIPODO, M.M.; D'AQUINO, A.; MONDELLO, M.R. Antiulcer activity of Opuntia ficus indica (L.) Mill. (Cactaceae): ultrastructural study. J. Ethnopharmacol., v.76, n.1, p.1-9, 2001.

GALATI, E.M.; PERGOLIZZI, S.; MICELI, N.; MONFORTE, M.T.; TRIPODO, M.M. Study on the increment of the production of gastric mucus in rats treated with Opuntia ficus indica (L.) Mill. cladodes. J. Ethnopharmacol., v.83, n.3, p.229-233, 2002a.

GALATI, E.M.; TRIPODO, M.M.; TROVATO, A.; MICELI, N.; MONFORTE, M.T. Biological effect of Opuntia ficus indica (L.) Mill. (Cactaceae) waste matter: Note I: diuretic activity. J. Ethnopharmacol., v.79, n.1, p.17-21, 2002 b. 
GIANETI, M.D.; MERCURIO, D.G.; MAIA CAMPOS, P.M.B.G. The use of green tea extract in cosmetic formulations: not only an antioxidant active ingredient. Dermatol. Ther, v.26, n.3, p.267-271, 2013.

GINESTRA, G.; PARKER, M.L.; BENNETT, R.N.; ROBERTSON, J.; MANDALARI, G.; NARBAD, A.; LO CURTO, R.B.; BISIGNANO, G.; FAULDS, C.B.; WALDRON, K.W. Anatomical, chemical, and biochemical characterization of cladodes from prickly pear [Opuntia ficus-indica (L.) Mill.]. J. Agric. Food Chem., v.57, n.21, p.10323-10330, 2009.

GONÇALVES, G.M.S.; MAIA CAMPOS, P.M.B.G. Aplicação de métodos de biofísica no estudo da eficácia de produtos dermocosméticos. Braz. J. Pharm. Sci., v.45, n.1, p.1-10, 2009a.

GONÇALVES, G.M.S.; MAIA CAMPOS, P.M.B.G. Shelf life and rheology of emulsions containing vitamin $\mathrm{C}$ and its derivatives. Rev. Ciênc. Farm. Básica Apl., v.30, n.2, p.217-224, 2009b.

GUARATINI, T.; GIANETI, M.D.; CAMPOS, P.M.B.G.M. Stability of cosmetic formulations containing esters of vitamins $\mathrm{E}$ and $\mathrm{A}$ : chemical and physical aspects. Int. J. Pharm., v.327, n.1-2, p.12-16, 2006.

HEINRICH, U.; KOOP, U.; LENEVEU-DUCHEMIN, M.C.; OSTERRIEDER, K.; BIELFELDT, S.; CHKARNAT, C.; DEGWERT, J.; HÄNTSCHEL, D.; JASPERS, S.; NISSEN, H.P.; ROHR, M.; SCHNEIDER, G.; TRONNIER, $\mathrm{H}$. Multicentre comparison of skin hydration in terms of physical-, physiological - and product-dependent parameters by the capacitive method (Corneometer CM 825). Int. J. Cosmet. Sci., v.25, n.1-2, p.45-53, 2003.

KAPOOR, S.; SARAF, S. Assessment of viscoelasticity and hydration effect of herbal moisturizers using bioengineering techniques. Pharmacogn. Mag., v.6, n.24, p.298-304, 2010.

LEITE-SILVA, V.R.; LAMER, M.L.; SANCHEZ, W.Y.; LIU, D.C.; SANCHEZ, W.H.; MORROW, I.; MARTIN, D.; SILVA, H.D.T.; PROW, T.W.; GRICE, J.E.; ROBERTS, M.S. The effect of formulation on the penetration of coated and uncoated zinc oxide nanoparticles into the viable epidermis of human skin in vivo. Eur. J. Pharm. Biopharm., v.84, n.2, p.297-308, 2013.
LEITE E SILVA, V.R.; SCHULMAN, M.A.; FERELLI, C.; GIMENIS, J.M.; RUAS, G.W.; BABY, A.R.; VELASCO, M.V.R.; TAQUEDA, M.E.; KANEKO, T.M. Hydrating effects of moisturizer active compounds incorporated into hydrogels: in vivo assessment and comparison between devices. J. Cosmet. Dermatol., v.8, n.1, p.32-39, 2009.

LIMA, C.G.; VILELA, A.F.G.; SILVA, A.A.S.; PIANNOVSKI, A.R.; SILVA, K.K.; CARVALHO, V.F.M.; DE MUSIS, C.R.; MACHADO, S.R.P.; FERRARI, M. Desenvolvimento e avaliação da estabilidade física de emulsões $\mathrm{O} / \mathrm{A}$ contendo óleo de babaçu (Orbignya oleifera). Rev. Bras. Farm., v.89, n.3, p.239-245, 2008.

LINS, R.D.; PEREIRA, C.S.; HÜNENBERGER, P.H. Trehalose-protein interaction in aqueous solution. Proteins: Struct., Funct., Bioinf., v.55, n.1, p.177-186, 2004.

MAHMOOD, T.; AKHTAR, N. Stability of a cosmetic multiple emulsion loaded with green tea extract. Sci. W. J., v.2013, p.7, 2013.

MAIA CAMPOS, P.M.B.G.; CAMARGO JUNIOR, F.B.; ANDRADE, J.P.; GASPAR, L.R. Efficay of cosmetic formulations containing dispersion of liposome with magnesium ascorbyl phosphate, alpha-lipoic acid and kinetin. Photochem. Photobiol., v.88, n.3, p.748-752, 2012.

MORAVKOVA, T.; FILIP, P. The influence of emulsifier on rheological and sensory properties of cosmetic lotions. $A d v$. Mat. Sci. Eng., v.2013, p.7, 2013.

MORGANTI, P. Use and potential of nanotechnology in cosmetic dermatology. Clin. Cosmet. Investig. Dermatol., v.3, p.5, 2010.

OHTAKE, S.; WANG, Y.J. Trehalose: current use and future applications. J. Pharm. Sci., v.100, n.6, p.2020-2053, 2011.

PANICO, A.M.; CARDILE, V.; GARUFI, F.; PUGLIA, C.; BONINA, F.; RONSISVALLE, S. Effect of hyaluronic acid and polysaccharides from Opuntia ficus indica (L.) cladodes on the metabolism of human chondrocyte cultures. J. Ethnopharmacol., v.111, n.2, p.315-321, 2007.

PARK, E.H.; CHUN, M.J. Wound healing activity of Opuntia ficus-indica. Fitoterapia, v.72, n.2, p.165-167, 2001. 
PAYS, K.; GIERMANSKA-KAHN, J.; POULIGNY, B.; BIBETTE, J.; LEAL-CALDERON, F. Double emulsions: how does release occur? J. Control. Rel., v.79, n.1-3, p.193$205,2002$.

PIANOVSKI, A.R.; VILELA, A F.G.; SILVA, A.A.S.D.; LIMA, C.G.; SILVA, K.K.D.; CARVALHO, V.F.M.; MUSIS, C.R.D.; MACHADO, S.R.P.; FERRARI, M. Uso do óleo de pequi (Caryocar brasiliense) em emulsões cosméticas: desenvolvimento e avaliação da estabilidade física. Rev. Bras. Ciênc. Farm., v.44, n.2, p.249-259, 2008.

PIÉRARD, G.E. Instrumental non-invasive assessments of cosmetic efficacy. J. Cosmet. Dermatol., v.1, n.2, p.57-58, 2002.

POLASKOVA, J.; PAVLACKOVA, J.; EGNER, P. Effect of vehicle on the performance of active moisturizing substances. Skin Res. Technol., v.21, n.4, p.403-12, 2015.

RAMADAN, M.F.; MÖRSEL, J.-T. Recovered lipids from prickly pear [Opuntia ficus-indica (L.) Mill] peel: a good source of polyunsaturated fatty acids, natural antioxidant vitamins and sterols. Food Chem., v.83, n.3, p.447-456, 2003.

RAPITHIX. Rheology modifiers for personal care: tecnical literature. New Jersey, 2003. 8p.

RIBEIRO, C. Cosmetologia aplicada a dermoestética. 2. ed. São Paulo: Pharmabooks, 2010. 441p.

RIBEIRO, R.C.A.; BARRETO, S.M.A.G.; OSTROSKY, E.A.; ROCHA-FILHO, P.A.; VERÍSSIMO, L.M.; FERRARI, M. Production and characterization of cosmetic nanoemulsions containing Opuntia ficus-indica (L.) Mill extract as moisturizing agent. Molecules, v.20, n.2, p.2492-2509, 2015.

SEPIGEL 305. Tecnical literature. 2013 Available at: http:// $<$ www.fagron.com.br/Produtos/MateriaPrima $>$. Accessed on: 01 Sep. 2014.

SOTOODIAN, B.; MAIBACH, H.I. Noninvasive test methods for epidermal barrier function. Clin. Dermatol, v.30, n.3, p.301-310, 2012.

STINTZING, F.C.; CARLE, R. Cactus stems (Opuntia spp.): A review on their chemistry, technology, and uses. Mol. Nutr. Food Res., v.49, n.2, p.175-194, 2005.
TADROS, T. Application of rheology for assessment and prediction of the long-term physical stability of emulsions. Adv. Colloid. Interf. Sci., v.108-109, p.227-258, 2004.

TADROS, T. Interparticle interactions in concentrated suspensions and their bulk (Rheological) properties. $A d v$. Colloid Interf. Sci., v.168, n.1-2, p.263-277, 2011.

TCHOLAKOVA, S.; DENKOV, N.D.; IVANOV, I.B.; CAMPBELL, B. Coalescence stability of emulsions containing globular milk proteins. Adv. Colloid Interf. Sci., v.123-126, p.259-293, 2006.

VIANNA-FILHO, R.P.; PETKOWICZ, C.L.O.; SILVEIRA, J.L.M. Rheological characterization of $\mathrm{O} / \mathrm{W}$ emulsions incorporated with neutral and charged polysaccharides. Carbohydr. Polym., v.93, n.1, p.266-272, 2013.

WANG, J.; JIN, W.; HOU, Y.; NIU, X.; ZHANG, H.; ZHANG, Q. Chemical composition and moisture-absorption/ retention ability of polysaccharides extracted from five algae. Int. J. Biol. Macromol., v.57, p.26-29, 2013.

WEN, L.; PAPADOPOULOS, K.D. Effects of osmotic pressure on water transport in $\mathrm{W} 1 / \mathrm{O} / \mathrm{W} 2$ emulsions. J. Colloid Interf. Sci., v.235, n.2, p.398-404, 2001.

WHARTON, D.A. Anhydrobiosis: the model worm as a model? Curr. Biol., v.21, n.15, p.R578-R579, 2011.

ZHANG, Z.-S.; WANG, X.-M.; HAN, Z.-P.; ZHAO, M.-X.; YIN, L. Purification, antioxidant and moisture-preserving activities of polysaccharides from papaya. Carbohydr. Polym., v.87, n.3, p.2332-2337, 2012.

ZHONG, X.-K.; JIN, X.; LAI, F.-Y.; LIN, Q.-S.; JIANG, J.-G. Chemical analysis and antioxidant activities in vitro of polysaccharide extracted from Opuntia ficus indica Mill. cultivated in China. Carbohydr. Polym., v.82, n.3, p.722$727,2010$.

Received for publication on $28^{\text {th }}$ August 2015 Accepted for publication on $15^{\text {th }}$ August 2016 